\title{
Oropharyngeal Cancer cM1 TNM Finding v7
}

National Cancer Institute

\section{Source}

National Cancer Institute. Oropharyngeal Cancer CM1 TNM Finding V7. NCI Thesaurus.

Code C89020.

Oropharyngeal cancer with distant metastasis. (from AJCC 7th Ed.) 